\title{
Cycle Analysis of Micro Gas Turbine-Molten Carbonate Fuel Cell Hybrid System*
}

\author{
Shinji KIMIJIMA** and Nobuhide KASAGI ${ }^{* * *}$
}

\begin{abstract}
A hybrid system based on a micro gas turbine ( $\mu \mathrm{GT})$ and a high-temperature fuel cell, i.e., molten carbonate fuel cell (MCFC) or solid oxide fuel cell (SOFC), is expected to achieve a much higher efficiency than conventional distributed power generation systems. In this study, a cycle analysis method and the performance evaluation of a $\mu$ GT-MCFC hybrid system, of which the power output is $30 \mathrm{~kW}$, are investigated to clarify its feasibility. We developed a general design strategy in which a low fuel input to a combustor and higher MCFC operating temperature result in a high power generation efficiency. A high recuperator temperature effectiveness and a moderate steam-carbon ratio are the requirements for obtaining a high material strength in a turbine. In addition, by employing a combustor for complete oxidation of MCFC effluents without additional fuel input, i.e., a catalytic combustor, the power generation efficiency of a $\mu \mathrm{GT}-\mathrm{MCFC}$ is achieved at over $60 \%$ (LHV).
\end{abstract}

Key Words: Gas Turbine, Fuel Cell, Thermal Efficiency, Exergy, Energy Saving, Hybrid System, Cycle Analysis

\section{Introduction}

Recently, technological development toward the effective use of energy has been encouraged. Small distributed energy systems, which are based on small-scale engines and fuel cells, are expected to contribute to energy saving $^{(1)}$. Micro gas turbines ( $\mu \mathrm{GTs}$ ), of which power outputs are below $100 \mathrm{~kW}$, have been developed ${ }^{(2)}$, however the power generation efficiencies of practical $\mu \mathrm{GTs}$ are below $30 \%$. The performance improvement of $\mu$ GTs is a significant technical issue ${ }^{(3)}$. Responding to this situation, hybrid systems, which consist of gas turbines and fuel cells, have been suggested, and diversified research results have been reported ${ }^{(4)}$. Considering the operating temperature ranges of gas turbines and fuel cells, the molten carbonate fuel cell (MCFC) and solid oxide fuel cell (SOFC) are suitable for coupling with gas turbines.

* Received 7th May, 2004 (No. 02-0676). Japanese Original: Trans. Jpn. Soc. Mech. Eng., Vol.69, No.680, B (2003), pp.1001-1008 (Received 22nd May, 2003)

** Department of Machinery and Control Systems, Shibaura Institute of Technology, 307 Fukasaku, Minuma-ku, Saitama-shi, Saitama 337-8570, Japan.

E-mail: kimi@sic.shibaura-it.ac.jp

*** Department of Mechanical Engineering, The University of Tokyo, 7-3-1 Hongo, Bunkyo-ku, Tokyo 113-8656, Japan
Generally, MCFCs are operated in the temperature range of $650^{\circ} \mathrm{C}$ to $700^{\circ} \mathrm{C}$. Hence, MCFCs can be operated with various types of fuel, e.g., hydrocarbon from natural gas and gasified coal. Such fuel flexibility is one of the features of MCFCs. This type of fuel cell is expected for wide applications, i.e., in alternative large-scale thermal power generation plants and small-scale distributed power generation plants, of which the power outputs are 300$400 \mathrm{~kW}^{(5)}$.

At present, some technical reports regarding highly efficient power generation systems including MCFCs, e.g., the combination with bottom cycles using steam or an ammonia-water mixture ${ }^{(6)}$ and gas turbine cycles ${ }^{(7)}$, can be found. There are various MCFCs and thermal power cycle combined systems. Hence, in the stage of system design and planning, the optimization of system configurations based on the proper objective function is essential to develop high-performance combined energy systems. As mentioned above, various system analyses with respect to the combination of MCFCs and heat engines have been conducted. In some articles ${ }^{(8)-(13)}$, it has been clarified that hybrid systems have the potential to achieve an extremely high efficiency of over $60 \%$. Hybrid systems, of which the power output scales are relatively large $(>1.0 \mathrm{MW})$, are discussed in many previous studies. However, assuming the application of these systems as a smallscale distributed power supply to meet the energy demand 
of the consumer sector, i.e., commercial buildings, offices, hotels and hospitals, the significant technical issues of small hybrid systems should be investigated.

In the present paper, the cycle analysis of a $\mu \mathrm{GT}$ MCFC hybrid system, of which the power output is $30 \mathrm{~kW}$ is described. In particular, the effects of major design parameters on the performance of the hybrid system are discussed in detail, and the design strategy for the practical application of hybrid systems technology is discussed.

\section{Nomenclature}

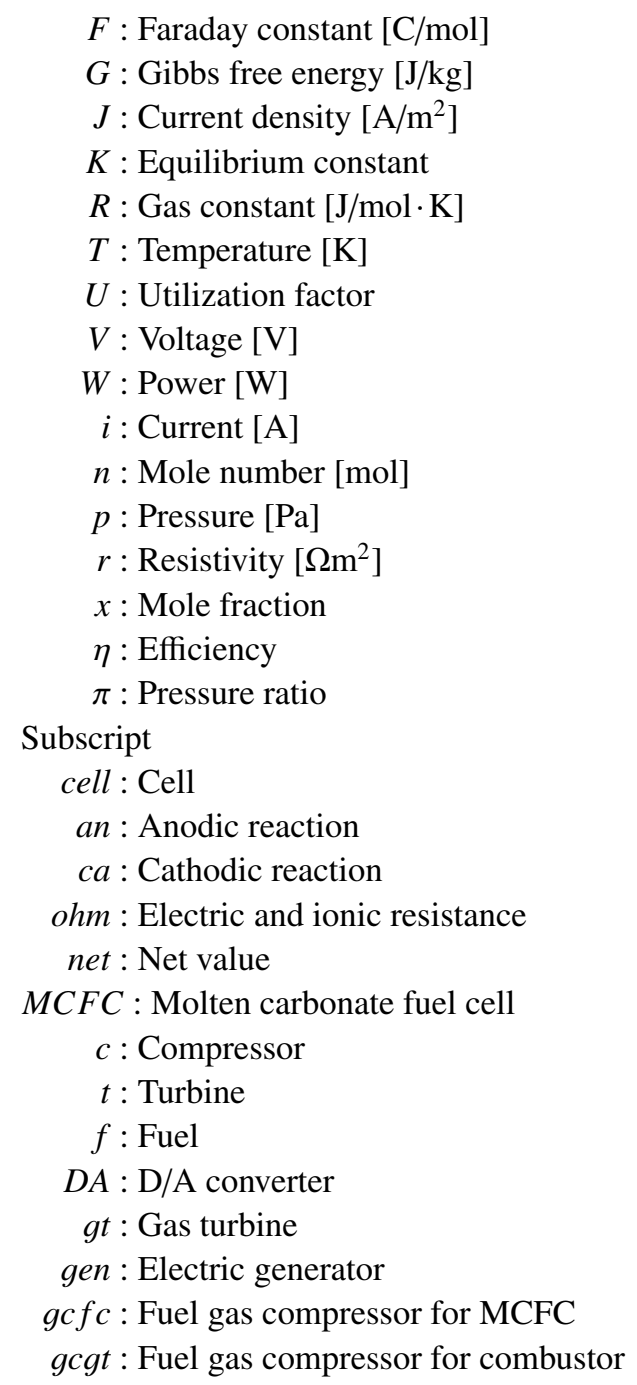

\section{Overview of $\boldsymbol{\mu G T - M C F C ~ H y b r i d ~ S y s t e m ~}$}

On the basis of the operating modes of gas turbines, hybrid systems made up of a gas turbine and a MCFC are classified into two different types. The first one is a gas turbine directly driven with the exhaust heat of a MCFC thus enabling power recovery. The second one is the closed gas turbine indirectly driven with the waste heat recovered in a heat exchanger. In the latter case, the pressure ratio of a gas turbine cycle can be adjusted regardless of MCFC operating pressure. Considering the cell performance improvement caused by pressurization and the ef-

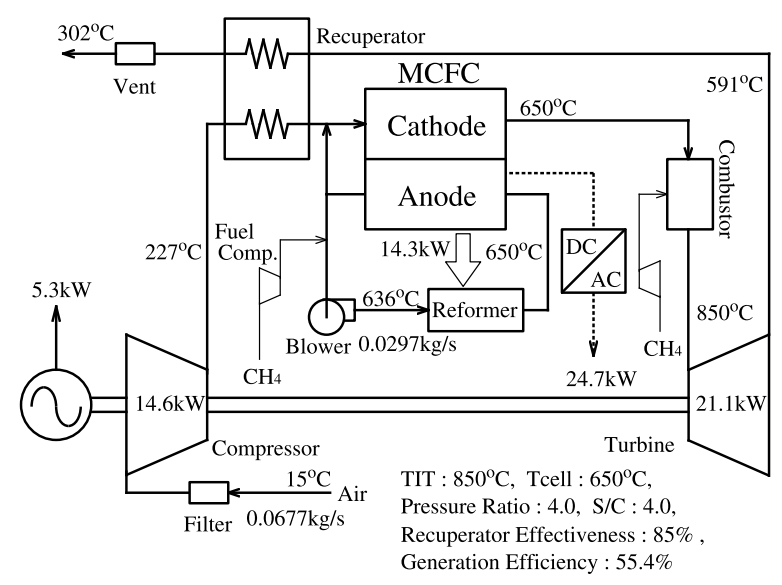

Fig. 1 Schematic diagram of $\mu$ GT-MCFC hybrid system

fectiveness of direct gas turbine driving using the hot exhaust of a MCFC, the basic configuration of the hybrid system described in this paper is a recuperated gas turbine cycle with a MCFC, which is placed downstream of a compressor. Figure 1 shows a schematic diagram of the $\mu \mathrm{GT}-\mathrm{MCFC}$ hybrid system. This system is operated using methane at atmospheric temperature and pressure $\left(15^{\circ} \mathrm{C}\right.$ and $101.325 \mathrm{kPa}$ ) as a primary fuel. The pressurized air from the compressor is heated in the recuperator using the exhaust gas from the turbine, and is subsequently supplied into the cathode of the MCFC. The anode exhaust gas of the MCFC contains residual species, i.e., hydrogen, carbon monoxide and methane. These combustible chemical species are completely oxidized in the combustor. The high-temperature combustion gas directly expands in the turbine to generate mechanical power and is discharged after heating the compressed air in the recuperator. With respect to fuel reforming, indirect internal reforming is employed and the required steam is supplied with the anode exhaust recirculation. Generally, carbonate ions pass through electrolytes in MCFCs. In order to operate a MCFC, carbon dioxide should be injected into the cathode fill port. In the present system, the recirculation path in which some of the anode exhaust is mixed with the cathode inlet air is taken into consideration ${ }^{(14)}$. The numeric values in Fig. 1 indicate a typical example of the cycle calculation results based on certain design conditions. Assuming that the total power output is $30 \mathrm{~kW}$, the $\mu \mathrm{GT}-\mathrm{MCFC}$ hybrid system has prospects that its power generation efficiency reaches approximately 55\% (LHV).

\section{Cycle Analysis Method}

\subsection{Assumptions and calculation conditions}

Regarding the performance evaluation of a MCFC, it is found that two-dimensional modelling and numerical simulations of planar cells are described in detail in previous papers. These previous research studies deal with the conjugated phenomena of electrochemical reaction, 
heat/mass transfer and fluid flow ${ }^{(15)-(18)}$, and effective information for actual cell design is pointed out by clarifying internal distributions of temperatures and other parameters. On the contrary, in this paper we intend to evaluate comprehensive characteristics and show the theoretically prospective performance of the $\mu \mathrm{GT}-\mathrm{MCFC}$ hybrid system. Hence, the following matters are assumed in order to simplify cycle analysis.

(1) There are no leakages of working fluids.

(2) Heat losses are negligibly small.

(3) Chemical reaction completely proceeds to equilibrium states.

( 4 ) Chemical reaction proceeds under uniform temperature, pressure and composition. There is no distribution of physical values in all components.

( 5 ) Steady-state operation is considered.

(6) The temperatures of the anode outlet, cathode outlet and reformer outlet are equal to the MCFC operating temperature.

( 7 ) The unburnt combustible content in anode exhaust gas, i.e., hydrogen, carbon monoxide, methane and additional fuel (methane), are completely oxidized in the downstream combustor.

In this study, the total power output is set at $30 \mathrm{~kW}$, because the hybrid system is assumed to be used as smallscale distributed power generation equipment. In the case of small-scale systems, heat losses will actually be significant issues, however definite system design, which includes the arrangement of components, is not the target of the present study. The focus of this paper is the thermodynamic performance evaluation, hence we do not take heat losses into account and discuss the ideal characteristics of the hybrid system. The standard calculation condition is shown in Table 1. The adiabatic efficiencies of the compressor and turbine are determined from a previous report of a gas turbine, of which the power output is $10 \mathrm{~kW}^{(19)}$. The other values are appropriate assumptions in terms of the current technology level and compactness of the system.

\subsection{Reaction heat and equilibrium constant}

Reaction heat is estimated as the difference in formation enthalpy. Equilibrium constants are calculated from the formation Gibbs free energy $\Delta G$, gas constant $R$ and reaction temperature $T$.

$$
K=\exp (-\Delta G / R T)
$$

The thermophysical and thermochemical properties of working fluids except methane are obtained from JANAF tables $^{(20)}$. The properties of methane are referred to in the chemical engineering handbook ${ }^{(21)}$.

\subsection{Micro gas turbine}

State changes of working gases in a compressor and turbine are calculated using the method described in the literature $^{(22)}$. The values of the compressor power con-
Table 1 Standard calculation condition

\begin{tabular}{|c|c|}
\hline Total Output (kW) & 30 \\
\hline Recuperator Temperature Effectiveness (\%) & 85 \\
\hline Compressor Adiabatic Efficiency (\%) & 73 \\
\hline Turbine Adiabatic Efficiency (\%) & 80 \\
\hline GT Mechanical Efficiency (\%) & 95 \\
\hline Blower Adiabatic Efficiency (\%) & 70 \\
\hline Blower Mechanical Efficiency (\%) & 90 \\
\hline Gas Compressor Adiabatic Efficiency (\%) & 60 \\
\hline Gas Compressor Mechanical Efficiency (\%) & 90 \\
\hline Steam Carbon Ratio (-) & 3 \\
\hline Current Density $\left(\mathrm{A} / \mathrm{m}^{2}\right)$ & 1500 \\
\hline $\mathrm{H}_{2}$ Utilization $(\%)$ & 80 \\
\hline MCFC Pressure Drop (\%) & 5 \\
\hline Reformer Pressure Drop (\%) & 4 \\
\hline Filter Pressure Drop (\%) & 0.5 \\
\hline Vent Pressure Drop (\%) & 0.5 \\
\hline Recuperator Pressure Drop (Air Side) (\%) & 3 \\
\hline Recuperator Pressure Drop (Exhaust Side) (\%) & 2 \\
\hline Atmosphere Temperature $\left({ }^{\circ} \mathrm{C}\right)$ & 15 \\
\hline Generator Efficiency (\%) & 98 \\
\hline Inverter Efficiency $(\%)$ & 93 \\
\hline
\end{tabular}

sumption $W_{c}$ and the turbine power output $W_{t}$ are estimated from the inlet and outlet gas conditions, thereby the net power output of the gas turbine $W_{g t}$ can be calculated in consideration of the mechanical efficiency of rotating components $\eta_{g t}$, the electric generator efficiency $\eta_{g e n}$ and the power consumption of the fuel compressor $W_{g c g t}$.

$$
W_{g t}=\eta_{g e n}\left(\eta_{g t} W_{t}-W_{c}\right)-W_{g c g t}
$$

\section{4 Fuel reforming process}

The chemical reactions in the steam reforming and shifting of methane are shown below.

$$
\begin{array}{ll}
\text { Reforming: } & \mathrm{CH}_{4}+\mathrm{H}_{2} \mathrm{O} \rightarrow \mathrm{CO}+3 \mathrm{H}_{2} \\
\text { Shifting: } & \mathrm{CO}+\mathrm{H}_{2} \mathrm{O} \rightarrow \mathrm{CO}_{2}+\mathrm{H}_{2}
\end{array}
$$

The reforming and shifting reactions are endothermic and exothermic, respectively. The contribution of reforming is larger than that of shifting, and therefore the overall steam reforming process should be endothermic. The temperature inside the reactor is estimated as the arithmetic mean of the cell and inflow gas temperatures. The equilibrium constant and reaction heat of this process are calculated using the above-described mean temperature. The number of molecules reacting is determined by the gas com- 
position under an inlet condition and equilibrium state, in which the required heat for steam reforming is estimated.

In the hybrid system shown in Fig. 1, the recirculation of the anode exhaust gas provides the required steam for the reforming process. On the basis of the steam mole number included in the inflow of recirculation gas $n_{a n, \mathrm{H}_{2} \mathrm{O}}$ and the mole number of supplied methane $n_{a n, \mathrm{CH}_{4}}$, the steam to carbon ratio $(\mathrm{S} / \mathrm{C})$ is defined as

$$
\mathrm{S} / \mathrm{C}=n_{a n, \mathrm{H}_{2} \mathrm{O}} / n_{\mathrm{CH}_{4}} .
$$

$\mathrm{S} / \mathrm{C}$ affects the required mass flow rate of anode exhaust gas recirculation.

\subsection{MCFC}

In the cell of a MCFC, only the following reaction proceeds. The synthetic reaction of methane from hydrogen and carbon monoxide is excluded in the present cycle analysis.

$$
\begin{array}{ll}
\text { Anode: } & \mathrm{H}_{2}+\mathrm{CO}_{3}^{2-} \rightarrow \mathrm{CO}_{2}+\mathrm{H}_{2} \mathrm{O}+2 \mathrm{e}^{-} \\
& \mathrm{CO}+\mathrm{CO}_{3}^{2-} \rightarrow 2 \mathrm{CO}_{2}+2 \mathrm{e}^{-} \\
\text {Cathode: } & \mathrm{O}_{2}+2 \mathrm{CO}_{2}+4 \mathrm{e}^{-} \rightarrow 2 \mathrm{CO}_{3}^{2-}
\end{array}
$$

The reaction amount of hydrogen $\Delta n_{\mathrm{H}_{2}}$ is determined from the fuel utilization factor $U_{f}$, which is defined as

$$
U_{f}=\Delta n_{\mathrm{H}_{2}} / n_{a n, \mathrm{H}_{2}} .
$$

Furthermore, the reaction amount of carbon monoxide is obtained from the relationship in chemical equilibrium. The definition of the equilibrium constant gives the oxygen partial pressure in the anode $p_{a n, \mathrm{O}_{2}}$ as the following relational expression.

$$
p_{a n, \mathrm{O}_{2}}=\left(\frac{1}{K_{\mathrm{H}_{2}}} \frac{p_{a n, \mathrm{H}_{2} \mathrm{O}}}{p_{a n, \mathrm{H}_{2}}}\right)^{2}=\left(\frac{1}{K_{\mathrm{CO}}} \frac{p_{a n, \mathrm{CO}_{2}}}{p_{a n, \mathrm{CO}}}\right)^{2}
$$

Using the mole number $n$ and reaction amount $\Delta n$, Eq. (10) can be transcribed as described below.

$$
\frac{1}{K_{\mathrm{H}_{2}}} \frac{n_{a n, \mathrm{H}_{2} \mathrm{O}}+0.5 \Delta n_{\mathrm{H}_{2}}}{n_{a n, \mathrm{H}_{2}}-0.5 \Delta n_{\mathrm{H}_{2}}}=\frac{1}{K_{\mathrm{CO}}} \frac{n_{a n, \mathrm{CO}_{2}}+\Delta n_{\mathrm{CO}}+0.5 \Delta n_{\mathrm{H}_{2}}}{n_{a n, \mathrm{CO}}-0.5 \Delta n_{\mathrm{CO}}}
$$

Once the reaction amount of hydrogen $\Delta n_{\mathrm{H}_{2}}$ is obtained from Eq. (9), the reaction amount of carbon monoxide $\Delta n_{\mathrm{CO}}$ can be estimated by Eq. (11).

Theoretical voltage, namely Nernst voltage, caused by the cell reaction is calculated using

$$
V=-\frac{1}{2 F} \Delta G_{\mathrm{H}_{2}}-\frac{R T}{2 F} \ln \left(\frac{p_{a n, \mathrm{H}_{2} \mathrm{O}} p_{a n, \mathrm{CO}_{2}}}{p_{a n, \mathrm{H}_{2}} p_{c a, \mathrm{CO}_{2}} \sqrt{p_{c a, \mathrm{O}_{2}}}}\right) .
$$

\subsection{Evaluation of voltage drop in MCFC}

Generally, the current in a fuel cell reduces the voltage of output power, because some factors decrease voltage, i.e., ionic resistance, electric resistance, Nernst loss and the chemical reaction resistance caused by activation energy ${ }^{(23)}$. It is very difficult to exactly estimate the effects of these factors in conjunction with heat/mass transfer and electrochemical reaction on the cell performance. Hence, the prediction of the cell voltage deterioration, which is based on empirical expressions, is employed in the stage of MCFC design. A large variety of estimate equations, which are based on reaction temperatures and the partial pressure of each species, have been suggested $^{(23)-(25)}$. In the present study, the internal resistances of the MCFC are estimated using the following relational expressions ${ }^{(26),(27)}$. In these expressions, the ohmic resistance $r_{\text {ohm }}$ including the ionic and electric resistances, anodic reaction resistance $r_{a n}$ and cathodic reaction resistance $r_{c a}$ are reflected in the functions of the reaction temperatures and partial pressure of gas constituents.

$$
\begin{aligned}
& r_{\text {ohm }}=0.5 \times 10^{-4} \exp \left[3016 \times\left(\frac{1}{T_{\text {cell }}}-\frac{1}{923}\right)\right] \\
& r_{\text {an }}=2.27 \times 10^{-9} \exp \left(\frac{6435}{T_{\text {cell }}}\right) p_{a n, \mathrm{H}_{2}}^{-0.42} p_{\text {an }, \mathrm{CO}_{2}}^{-0.17} p_{a n, \mathrm{H}_{2} \mathrm{O}}^{-1.0} \\
& r_{c a}=7.505 \times 10^{-10} \exp \left(\frac{9298}{T_{\text {cell }}}\right) p_{c a, \mathrm{O}_{2}}^{-0.43} p_{c a, \mathrm{CO}_{2}}^{-0.09}
\end{aligned}
$$

The net voltage of the cell $V_{n e t}$ can be calculated from the theoretical voltage $V$ and the current density $J$ by

$$
V_{n e t}=V-J \times\left(r_{o h m}+r_{a n}+r_{c a}\right) \text {. }
$$

Figure 2 shows the relationship of the current density vs. the theoretical voltage (open circuit voltage) and the net voltage, which are calculated using Eqs. (12) and (16), respectively. In this case, theoretical voltage is $0.868 \mathrm{~V}$, and the voltage drop at the current density of $1500 \mathrm{~A} / \mathrm{m}^{2}$ is estimated to be $0.116 \mathrm{~V}$. Then, it is found that the net voltage should be $0.752 \mathrm{~V}$. This predicted value of the net voltage is at the same level as the measured data in previous reports $^{(28)-(30)}$.

The current $i$ is calculated by the mole numbers of the cell reactions $\Delta n_{\mathrm{H}_{2}}$ and $\Delta n_{\mathrm{CO}}$, and the Faraday number $F$.

$$
i=2 F \Delta n_{\mathrm{H}_{2}}+2 F \Delta n_{\mathrm{CO}}
$$

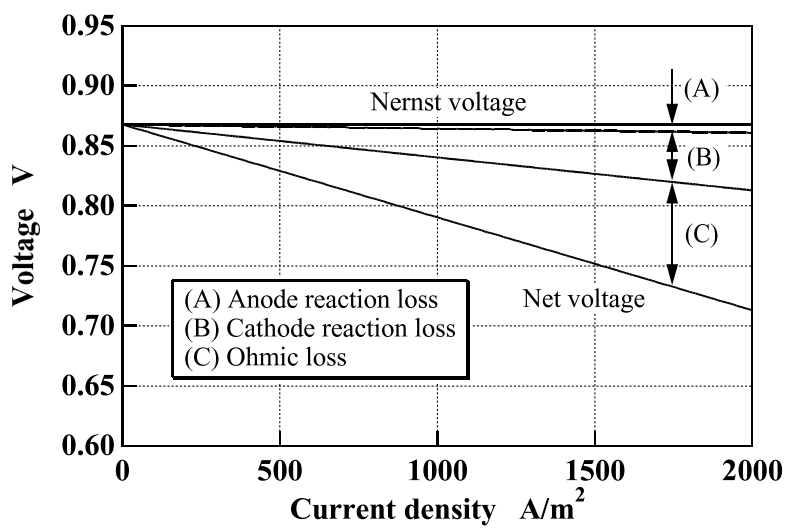

Pressure: 0.4MPa, Temperature: $650^{\circ} \mathrm{C}$, Gas composition (mole fraction)

Anode: $\mathrm{H}_{2} / \mathrm{H}_{2} / \mathrm{CO}_{2}=0.075 / 0.252 / 0.578$, Cathode: $\mathrm{O}_{2} / \mathrm{CO}_{2}=0.173 / 0.052$

Fig. 2 Cell voltage estimated using eqs. (12) and (16) 
Considering the power consumption in the fuel compressor $W_{g c f c}$ and the blower $W_{\text {blow }}$, and the conversion efficiency of the DC/AC converter $\eta_{D A}$, the net MCFC power output $W_{M C F C}$ can be estimated by

$$
W_{M C F C}=\eta_{D A} V_{\text {net }} i-W_{\text {gcfc }}-W_{\text {blow }} \text {. }
$$

\subsection{Power generation efficiency}

Through the use of the value of the total power output $\left(W_{g t}+W_{M C F C}\right)$ and the fuel input (mass flow rate) for the combustor $m_{g t}$ and the MCFC $m_{M C F C}$, the overall system efficiency for power generation $\eta_{s y s}$ is defined as

$$
\eta_{s y s}=\frac{W_{g t}+W_{M C F C}}{\left(m_{g t}+m_{M C F C}\right) \Delta H_{\mathrm{CH}_{4}}} .
$$

In this definition, the lower heating value at the temperature of $25^{\circ} \mathrm{C}$ is used as the calorific energy of methane $\Delta H_{\mathrm{CH}_{4}}$.

\section{Features of $\boldsymbol{\mu G T - M C F C ~ H y b r i d ~ S y s t e m ~}$}

In order to clarify the effectiveness of conjugating a gas turbine and a MCFC, performance evaluation based on an exergy analysis is revealed in this section. Exergy losses in the components of the hybrid system are estimated as the difference between the inflow and outflow exergies, which is calculated from the temperature, pressure, gas composition and mass flow rate ${ }^{(31)}$.

In the case that the operating temperature of the MCFC is $680^{\circ} \mathrm{C}$, the turbine inlet temperature (TIT) is $860^{\circ} \mathrm{C}$ and the pressure ratio of the turbine is 4.0, exergy breakdown can be obtained as shown in Fig. 3. Except for the parameters mentioned above, the calculation input values are the same as those cited in Table 1. In Fig. 3, the calculation results of a recuperated gas turbine cycle and an atmospheric MCFC are added to emphasize the features of the hybrid system. The exergy fraction of 58\% to the fuel input is transformed into the effective electric power. Compared with the recuperated gas turbine, the exergy loss in the combustor is appreciably reduced in the hybrid system. As against the atmospheric MCFC,

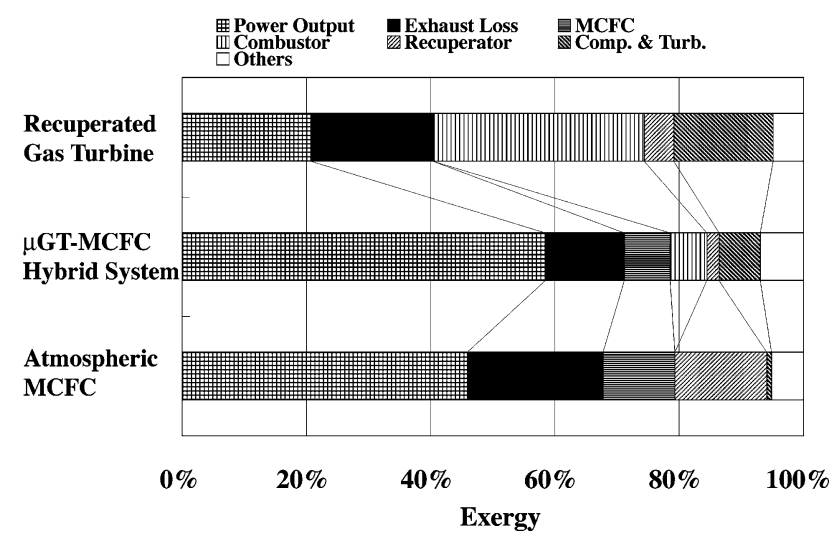

Fig. 3 Second-law losses in $\mu \mathrm{GT}-\mathrm{MCFC}$ hybrid system $\left(\right.$ Pressure ratio $=4.0, T_{\text {cell }}=680^{\circ} \mathrm{C}, \mathrm{TIT}=860^{\circ} \mathrm{C}$ ) the exhaust loss and exergy dissipation in the recuperator are lowered. In the atmospheric MCFC, preheating of the suction air using hot exhaust gas is taken into account, however the large temperature difference between the suction air and exhaust gas causes the exergy loss of the heat transfer process in the heat exchanger.

\section{Effects of Design Parameters on System Perfor- mance}

In this section, the effects of the main design parameters of the $\mu \mathrm{GT}-\mathrm{MCFC}$ hybrid system on the system performance are discussed in detail. The design parameters are divided into two categories. One category is largely dependent on the size of the component, e.g., the adiabatic efficiency of the compressor and turbine. The other has somewhat wide margins that can be adopted as designpoint values. We are concerned here only with the latter one, i.e., MCFC operating temperature (cell temperature), TIT and recuperator temperature effectiveness and S/C in the fuel reforming process. The effects of these parameters on the hybrid system performance are evaluated, and system design strategy is indicated in view of the constraint on the system operation.

\subsection{MCFC operating temperature and TIT}

Based on the data in Table 1 and a pressure ratio of 5.0, cycle analysis is executed with the cell temperature range from $550^{\circ} \mathrm{C}$ to $750^{\circ} \mathrm{C}$ at $50^{\circ} \mathrm{C}$ intervals, and the calculation results are shown in Fig. 4.

As show in Fig. 4 (a), a power generation efficiency of $55 \%$ is obtained with a cell temperature of $650^{\circ} \mathrm{C}$ and a TIT of $900^{\circ} \mathrm{C}$. In the case of a cell temperature of $700^{\circ} \mathrm{C}$ and a TIT of $950^{\circ} \mathrm{C}$, the efficiency attains over $60 \%$. Under the constant-cell-temperature condition, a high TIT decreases system performance. Because, as shown in Fig. 4 (b), a high TIT decreases fuel input to the MCFC, and fuel input to the combustor is boosted simultaneously. From the viewpoint of improving efficiency, decreasing fuel consumption in the combustor and decreasing TIT are effective, however the fuel input to the combustor reaches zero at a certain TIT and then a much lower TIT becomes impossible to set as the operating temperature. In this sense, the minimum TIT corresponding to the cell temperature is the temperature, which can be reached depending on the oxidation of the combustible species in the MCFC effluent gas. At this minimum TIT, the maximum power generation efficiency can be obtained. On the other hand, at a constant TIT, a higher cell temperature results in a much higher power generation efficiency, because hightemperature operation contributes to cell performance advancement, thereby making internal fuel reforming more beneficial. At the same time, proper temperature setting of the MCFC operation is essential to decrease the possibility of cell related problems, i.e., electrolyte scattering and shortened service life, which occur at a cell temperature 


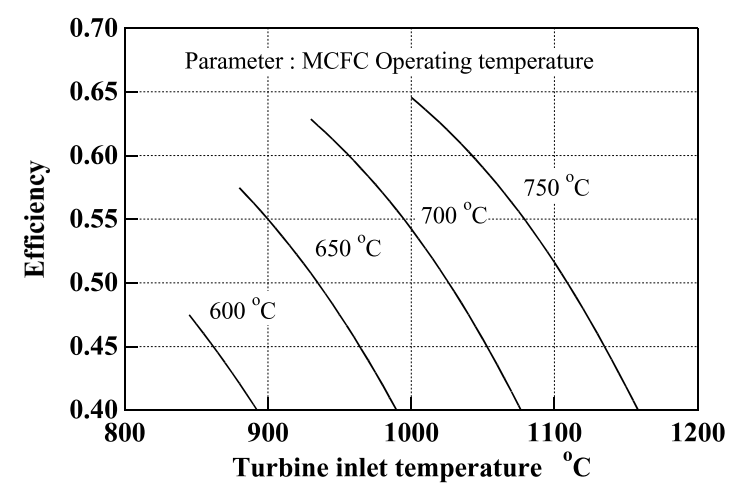

(a) Power generation efficiency (LHV)

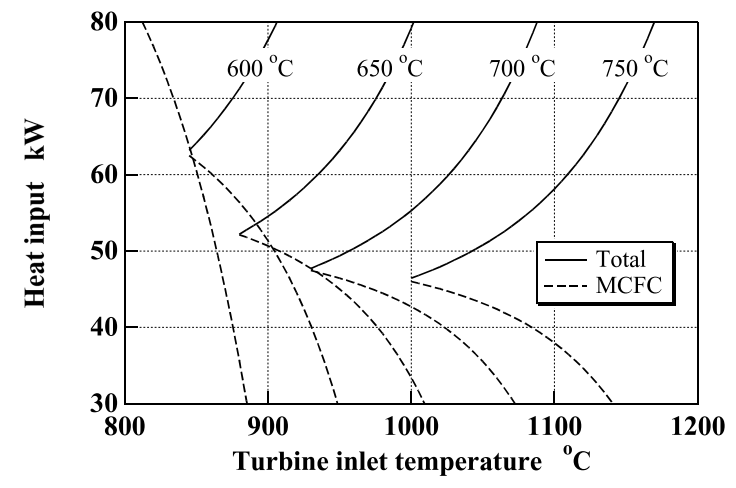

(b) Heat input (LHV)

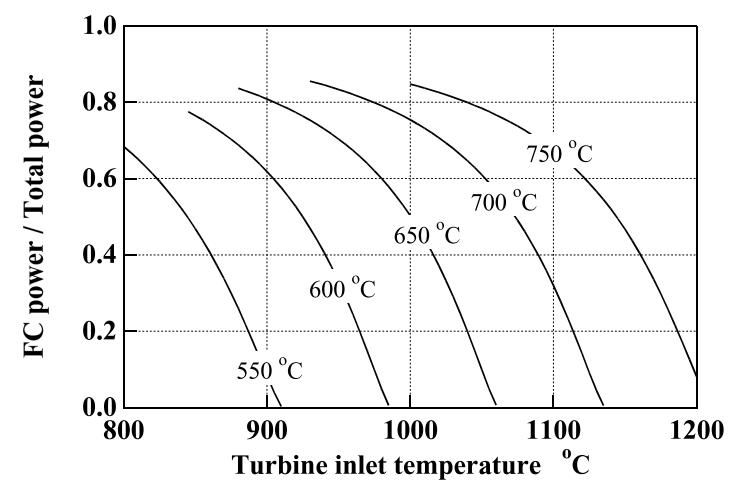

(c) Fractional power output of MCFC

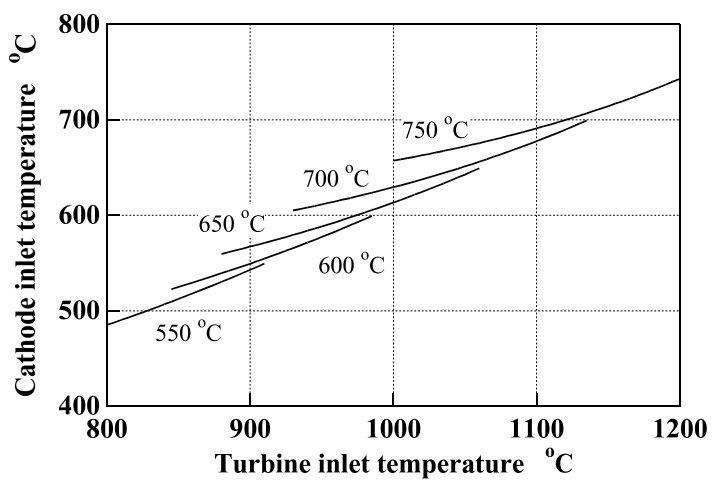

(d) Cathode inlet temperature

Fig. 4 Effects of MCFC operating temperature and TIT on characteristics of $\mu$ GT-MCFC hybrid system

over $700^{\circ} \mathrm{C}$.

Figure 4 (c) shows the fractional power output of the MCFC vs. the total power output of the hybrid system. A

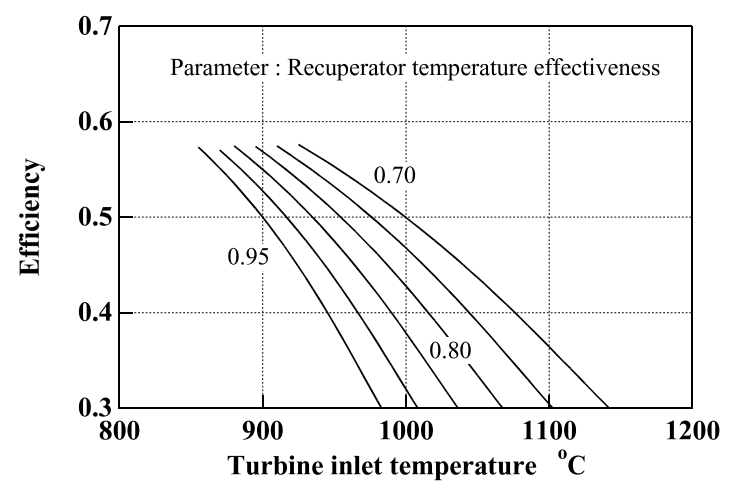

Fig. 5 Effects of recuperator temperature effectiveness on power generation efficiency (LHV)

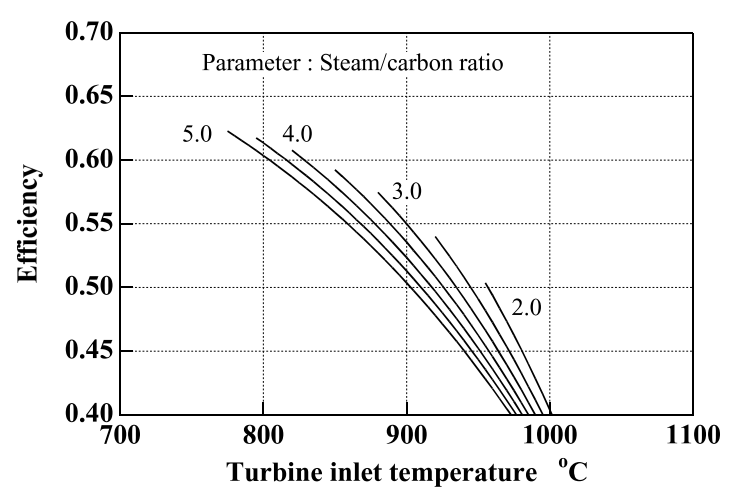

(a) Power generation efficiency (LHV)

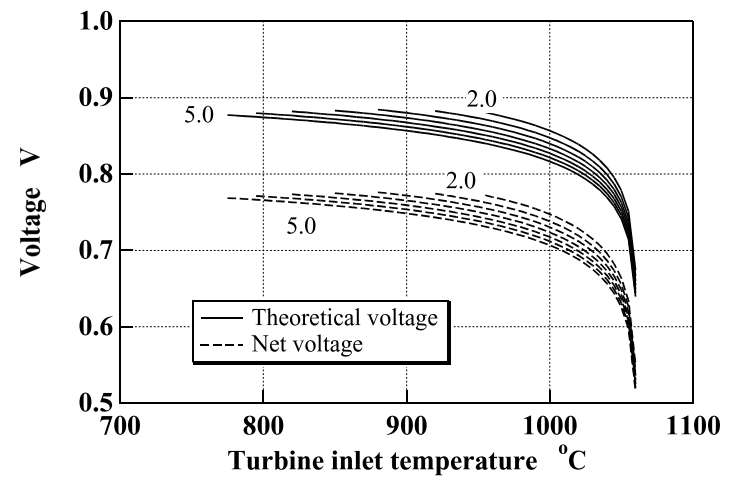

(b) Cell voltage

Fig. 6 Effects of steam/carbon ratio

large MCFC power output ratio improves system performance. Around the points, of which efficiency values are maximum at each cell temperature, the MCFC fractional power output ranges from $80 \%$ to $85 \%$.

Figure 4(d) shows the air temperature at the inlet of the cathode. As in MCFCs, supplied air should be heated at a temperature over the melting-point temperature of the carbonate material in the cell stack, e.g., approximately $490^{\circ} \mathrm{C}^{(32)}$ for $\mathrm{Li}_{2} \mathrm{CO}_{3} / \mathrm{K}_{2} \mathrm{CO}_{3}$ composite salt. In the present system, the cathode inlet temperature exceeds $550^{\circ} \mathrm{C}$ with a cell temperature of $650^{\circ} \mathrm{C}$, hence it is believed that this system has sufficient ability to drive without any problems. 


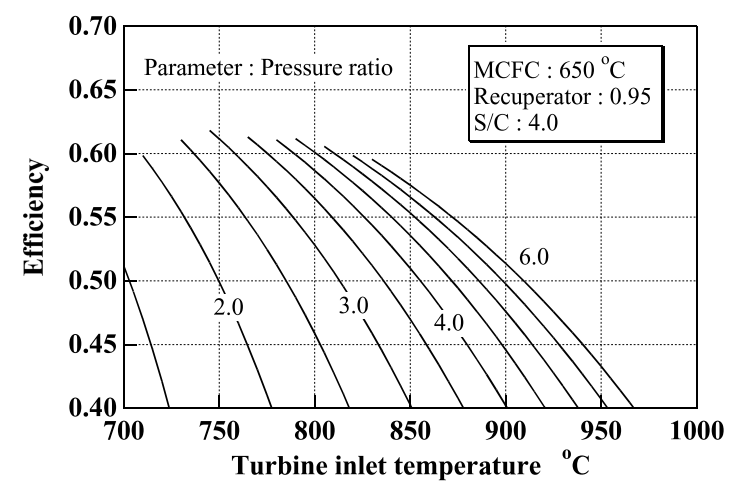

(a) Power generation efficiency (LHV)

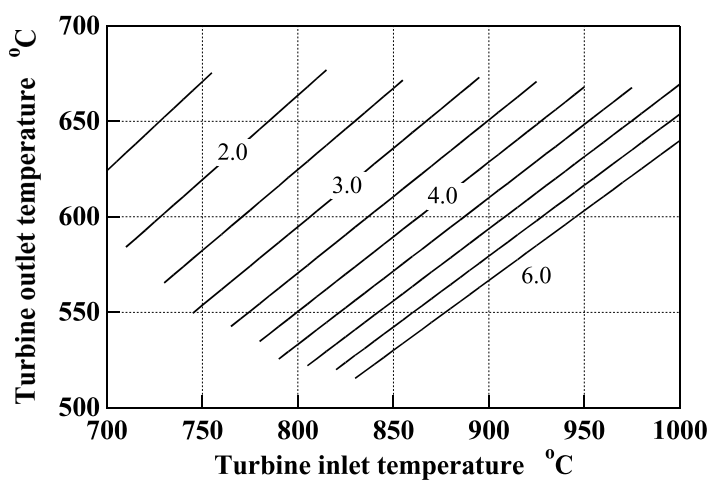

(b) Turbine outlet temperature

Fig. 7 Effects of pressure ratio ( $\mu$ GT-MCFC hybrid system)

\subsection{Recuperator temperature effectiveness}

Figure 5 shows the relationship between the TIT and the power generation efficiency. Each plotted curve represents a different recuperator temperature effectiveness of 0.7 to 0.95 in increments of 0.05 . At the same TIT, a high temperature effectiveness decreases the power generation efficiency of the hybrid system. Increasing temperature effectiveness raises air temperature at the cathode inlet, and then the temperature range in the cell decreases. A decrease in heat release from the cell is necessary for keeping cell temperature constant, and fuel input to the MCFC should be decreased. The required combustor fuel input is increased to boost the MCFC exhaust gas up to the required TIT, and the power generation efficiency decreases. However, the increase in recuperator temperature effectiveness decreases the required TIT to maintain the system efficiency and contributes to the control of the thermal durability constraint of the turbine material.

\subsection{Steam-to-carbon ratio}

Figure 6 shows the characteristics of the hybrid system with different $\mathrm{S} / \mathrm{C}$ settings from 2.0 to 5.0 in increments of 0.5. In Fig.6(a), which shows the relationship between TIT and the power generation efficiency, it is found that high $\mathrm{S} / \mathrm{C}$ degrades system performance. The high-S/C condition accelerates fuel reforming, and the mole fraction of methane at the inlet of the anode decreases. The partial pressure of hydrogen is decreased si-

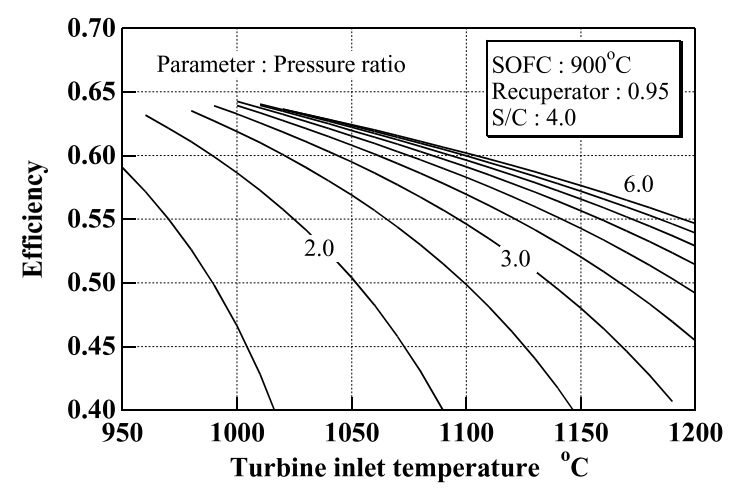

(a) Power generation efficiency (LHV)

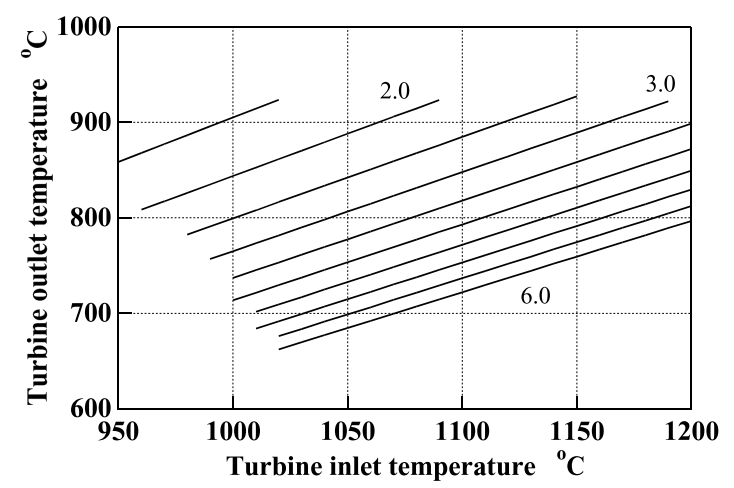

(b) Turbine outlet temperature

Fig. 8 Effects of pressure ratio ( $\mu$ GT-SOFC hybrid system)

multaneously by increasing the recirculation rate of the anode exhaust gas. From here onwards, the cell voltage decreases as shown in Fig. 6 (b). This voltage drop plays a role in the performance degradation of the hybrid system.

However, in a similar way as described in section 5.2, the high $\mathrm{S} / \mathrm{C}$ decreases the required TIT to obtain the same efficiency, and the heat resistance constraint of the turbine material is regulated. Actually, under the high-S/C condition, the oxidation of nickel, which is the component substance of electrodes, becomes a significant issue. In addition, the power consumption of the anode exhaust gas blower increases together with increasing recirculation flow rate. In consideration of the above described matters, proper setting of the $\mathrm{S} / \mathrm{C}$ is required for adequate system design.

\subsection{Pressure ratio}

Figure 7 shows the effects of pressure ratio in the range of 2.0 to 6.0 in increments of 0.5 . In this result, the recuperator temperature effectiveness is set at 0.95 and the $\mathrm{S} / \mathrm{C}$ is set at 4.0. As shown in Fig. 7 (a), a high pressure ratio offers a high power generation efficiency at the same TIT. Both of the turbine outlet gas temperature and the cathode inlet air temperature decrease with increasing pressure ratio. The fuel input to the MCFC and the amount of residual species in the anode effluent increase simultaneously. In this manner, a high pressure ratio causes a high TIT. However, a high pressure ratio increases tur- 
bine tip speed, and then the required thermal strength of the turbine material increases with increasing TIT. Thus an excessively high pressure ratio is not desirable.

\section{Comparison with $\mu$ GT-SOFC Hybrid System}

In the previously reported work ${ }^{(33)}$, the performance of a $\mu \mathrm{GT}-\mathrm{SOFC}$ hybrid system under the standard operating condition of a SOFC temperature of $1000^{\circ} \mathrm{C}$ has been evaluated. From the viewpoint of the easiness of system startup and shutdown, thermal durability of materials and cost reduction, a low SOFC operating temperature is favorable, namely a temperature in the range from $700^{\circ} \mathrm{C}$ to $800^{\circ} \mathrm{C}$ is required ${ }^{(34)}$. However, higher operating temperatures are preferred to improve efficiency. Figure 8 shows the calculation results of the $\mu \mathrm{GT}$-SOFC hybrid system under the conditions of a SOFC temperature of $900^{\circ} \mathrm{C}$, a current density of $3000 \mathrm{~A} / \mathrm{m}^{2}$, a recuperator temperature effectiveness of 0.95 and a $\mathrm{S} / \mathrm{C}$ of 4.0 , where the other parameters are set at the values in Table 1 , respectively.

Comparing Fig. 7 (a) with Fig. 8 (a), for example, the efficiency of the $\mu$ GT-SOFC hybrid system reaches $65 \%$ under the conditions of a pressure ratio of 4.0 and a TIT of $1000^{\circ} \mathrm{C}$. Thus the efficiency of the $\mu \mathrm{GT}-\mathrm{SOFC}$ hybrid system is higher than that of the $\mu$ GT-MCFC hybrid system. The fractional power output of the MCFC is greater than that of the SOFC, because the mechanical power generation of the turbine decreases due to the lower TIT of the $\mu$ GT-MCFC hybrid system. In the $\mu$ GT-SOFC hybrid system, the higher operating temperatures cause the higher TIT, and the turbine outlet temperatures (TOT) also become higher at the same pressure ratio as shown in Fig. 8 (b). In order to apply a metallic recuperator in hybrid systems, the highest limit of the turbine outlet temperature needs to be in the range from $800^{\circ} \mathrm{C}$ to $850^{\circ} \mathrm{C}^{(35)}$. It is not desirable to design a system with an excessively high TOT. Increasing the pressure ratio is favorable to control the thermal durability constraint of the recuperator materials. A high pressure ratio is effective for improving efficiency, however turbine tip speed is increased due to an increase in enthalpy drop. A high pressure ratio is actually impossible, hence taking not only efficiency but also material strength and cost into account is important when considering hybrid system design. In the near future, by developing of a $\mu \mathrm{GT}$ with a TIT of $1200^{\circ} \mathrm{C}$ and a SOFC with an operating temperature of $1000^{\circ} \mathrm{C}$, a very high efficiency, i.e., over $65 \%$ (LHV), can be expected ${ }^{(33)}$. On the contrary, the temperature of the MCFC exhaust gas after combustion of the residual species is consistent with the TIT of conventional $\mu \mathrm{GT}$, namely in the range from $800^{\circ} \mathrm{C}$ to $900^{\circ} \mathrm{C}$. Then, a conventional metallic recuperator can be applied to the hybrid system. In this manner, the feasibility of a much earlier practical application of $\mu \mathrm{GT}$ MCFC hybrid system is higher than that of $\mu \mathrm{GT}-\mathrm{SOFC}$ hybrid system due to the regulation of the turbine and re- cuperator materials.

\section{Investigation on Application of High-Temperature Catalytic Combustion}

The power generation efficiency of the hybrid system must be maximum at the point in which the additional fuel input to the combustor after the fuel cell is zero. A combustor, which can completely oxidize the combustible species in the MCFC exhaust without additional fuel consumption, is required. Figure 9 shows the calculation results regarding the hybrid system with high-temperature catalytic combustion $^{(36)}$ downstream of the MCFC. The effects of pressure ratio on system performance and TIT at different recuperator temperature effectivenesses are indicated in this figure. Since the additional fuel is zero, the TIT is determined by the enthalpy rise caused by the combustion of the residual species in the MCFC exhaust as shown in Fig. 9 (a). Analogous to general recuperative gas turbine cycles $^{(37)}$, the optimal pressure ratio, which gives the maximum efficiency, does exist. Disregarding the recuperator temperature effectiveness, a power generation efficiency of approximately $62 \%$ (LHV) can be expected at a pressure ratio of approximately $3.0-3.5$. The temperature effectiveness of the recuperator affects the TIT. The high effectiveness increases air mass flow rate, and decreases TIT. However, almost the same efficiency can be attained.

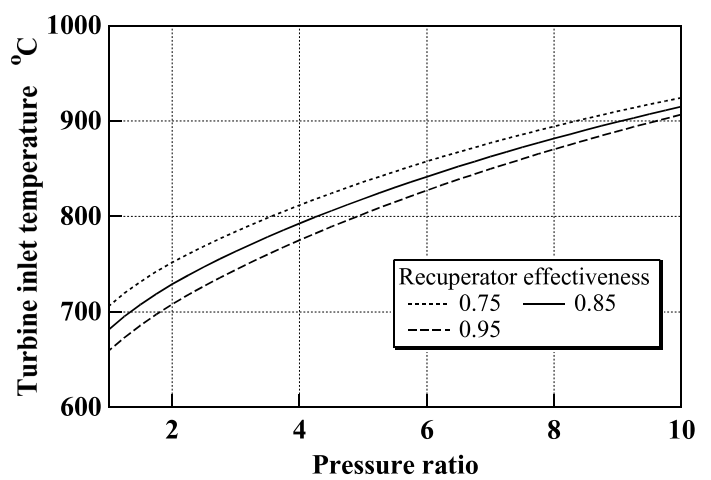

(a) Turbine inlet temperature

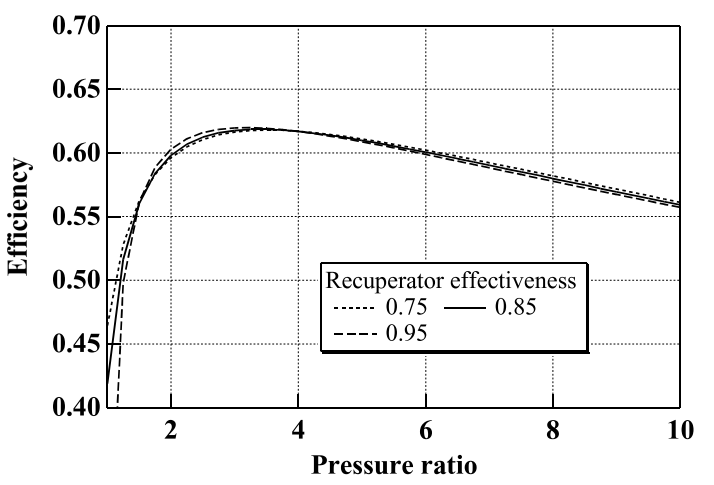

(b) Power generation efficiency (LHV)

Fig. 9 Characteristics of $\mu \mathrm{GT}-\mathrm{MCFC}$ hybrid system without additional fuel input to combustor 


\section{Conclusions}

In the present paper, the performance evaluation of the $\mu$ GT-MCFC hybrid system, which is based on the recuperated gas turbine cycle and the MCFC set upstream of the combustor, is discussed in detail. The derived results are described below.

(1) Under certain operating conditions, the $\mu \mathrm{GT}$ MCFC hybrid system has the potential to achieve the power generation efficiency of over 55\% (LHV).

(2) Compared with a conventional recuperative gas turbine cycle, the $\mu \mathrm{GT}-\mathrm{MCFC}$ hybrid system decreases combustor exergy loss. In comparison with an atmospheric MCFC, the exhaust loss can be reduced by the power recovery from the exhaust heat of the MCFC.

( 3 ) In order to improve power generation efficiency, the fuel consumption of the combustor, which is set downstream of the MCFC, should be reduced.

( 4 ) Improving the recuperator temperature effectiveness and decreasing TIT simultaneously, the power generation effciency can be increased and the thermal constraint of the turbine material can be regulated.

( 5 ) A high S/C controls the thermal constraint of the turbine material and improves system performance.

(6) System efficiency, the temperature limit of the recuperator and turbine tip speed, are important in determination of pressure ratio.

(7) Taking the material constraint into account, the early actual use of a $\mu$ GT-MCFC hybrid system can be expected with a much lower efficiency compared with a $\mu$ GT-SOFC hybrid system.

( 8 ) The installation of catalytic combustion technology ensures that the fuel input to the combustor is not necessary, hence a much higher system efficiency over $60 \%$ can be expected.

\section{Acknowledgements}

The authors would like to thank Mr. Uechi, H. and Mr. Kurahashi, K. at the university of Tokyo for their support in the development of the cycle analysis code. This work is supported through the Department of Core Research for Evolutional Science and Technology (CREST) of the Japan Science and Technology Agency (JST).

\section{References}

( 1 ) Hirata, M., Northeast Asian Distributed Energy System in the 21st Century: "Hydrogen Era", Proceedings of International Symposium on Distributed Energy System in the 21st Century, (2001), pp.S1-3-1-S1-3-12.

( 2 ) Kasagi, N., Micro Gas Turbine-Small Distributed Energy System, Kouatsu Gasu, (in Japanese), Vol.38, No.6 (2001), pp.544-552.

( 3 ) Kasagi, N., Hamana, Y., Okuda, H., Miwa, J. and Kimijima, S., Performance Test of a $28 \mathrm{~kW}$ Micro Gas
Turbine, Proceedings of the 29th Annual Gas Turbine Conference, (in Japanese), (2001), pp.83-88.

( 4 ) Layne, A., Williams, M., Samuelsen, S. and Holcombe, H., Hybrid Fuel Cell Heat Engines: Recent Efforts, ASME Paper, (2001), 2001-GT-588.

( 5 ) Watanabe, T., Hosaka, M., Yoshida, Y. and Ikematsu, M., Fuel Cell, Karyoku Genshiryoku Hatsuden, (in Japanese), Vol.52, No.10 (2001), pp.1326-1333.

( 6 ) Lovachyov, K.V. and Richter, H.J., Addition of Highly Efficient Bottoming Cycles for the $N$ th-Generation Molten Carbonate Fuel Cell Power Plant, Trans. ASME, Journal of Energy Resources Technology, Vol.119, No.2 (1997), pp.103-108.

( 7 ) Braun, R.J., Gaggioli, R.A. and Dunbar, W.R., Improvements of a Molten Carbonate Fuel Cell Power Plant via Exergy Analysis, Trans. ASME, Journal of Energy Resources Technology, Vol.121, No.4 (1999), pp.277-285.

( 8 ) Massardo, A.F. and Bosio, B., Assessment of Molten Carbonate Fuel Cell Models and Integration with Gas and Steam Cycles, Trans. ASME, Journal of Engineering for Gas Turbines and Power, Vol.124, No.1 (2002), pp.103-109.

(9) Lunghi, P., Ubertini, S. and Desideri, U., Highly Efficient Electricity Generation through a Hybrid Molten Carbonate Fuel Cell-Closed Loop Gas Turbine Plant, Energy Conversion and Management, Vol.42, No.14 (2001), pp.1657-1672.

(10) Lunghi, P. and Ubertini, S., Efficiency Upgrading of an Ambient Pressure Molten Carbonate Fuel Cell Plant through the Introduction of an Indirect Heated Gas Turbine, Trans. ASME, Journal of Engineering for Gas Turbines and Power, Vol.124 (2002), p.858-866.

(11) Campanari, S. and Macchi, E., The Investigation of Atmospheric Molten Carbonate Fuel Cells with Gas Turbine and Steam Cycles, ASME Paper, (2001), 2001GT-0382.

(12) Campanari, S. and Macchi, E., Comparative Analysis of Hybrid Cycles Based on Molten Carbonate and Solid Oxide Fuel Cells, ASME Paper, (2001), 2001GT-0383.

(13) Basurto, M.-T., Pericles, P. and Hales, R., Optimization Assessment of Hybrid MCFC-Gas Turbine Cycles, ASME Paper, (2001), 2001-GT-0090.

(14) Watanabe, T., Izaki, Y., Mugikura, Y., Abe T., Hamamatsu, T. and Ishikawa, H., Development of Molten Carbonate Fuel Cell Power Generation Technology (Development of 10-kW-Class Molten Carbonate Fuel Cell Generation System Test Facility), Trans. Jpn. Soc. Mech. Eng., (in Japanese), Vol.57, No.535, B (1991), pp.831-836.

(15) Wolf, T.L. and Wilemski, G., Molten Carbonate Fuel Cell Performance Model, Journal of Electrochemical Society, Vol.130, No.1 (1983), p.48-55.

(16) Kobayashi, N., Fujimura, H. and Ohtsuka, K., Heat and Mass Transfer in a Molten Carbonate Fuel Cell (1st Report, Experimental and Analytical Investigation of Fuel Cell Temperature Distribution), Trans. Jpn. Soc. Mech. Eng., (in Japanese), Vol.54, No.505, B (1988), pp.2568-2573. 
(17) Fujimura, H., Kobayashi, N. and Ohtsuka, K., Heat and Mass Transfer in a Molten Carbonate Fuel Cell (2nd Report, Analysis Investigation of Performance and Temperature Distribution in a Cell Stack), Trans. Jpn. Soc. Mech. Eng., (in Japanese), Vol.57, No.535, B (1991), pp.825-830.

(18) Yoshiba, H., Abe, T., Cao, G. and Watanabe, T., Investigation on Internal Condition of MCFC Stack (Numerical Analysis of Coflow-Type Stack), Trans. Jpn. Soc. Mech. Eng., (in Japanese), Vol.63, No.606, B (1997), pp.675-682.

(19) Rodgers, C., Performance Development History$10 \mathrm{~kW}$ Turboalternator, SAE Paper, (1974), 740849.

(20) Malcolm, W., NIST-JANAF Thermochemical Tables Fourth Edition, Part 1-Part 2, (1999), American Chemical Society and American Institute of Physics.

(21) The Society of Chemical Engineers Japan, Kagaku Kogaku Binran, (in Japanese), (1968), p.65, Maruzen.

(22) Gas Turbine Society of Japan (Examining Board), Numerical Equations for Thermodynamic Properties of Working Fluids in Gas Turbine, Journal of Gas Turbine Society of Japan, (in Japanese), Vol.13, No.52 (1986), p.55-62.

(23) Mugikura, Y., Abe, T., Watanabe, T. and Izaki, Y., Analysis of Performance of Molten Carbonate Fuel Cell II, Development of a Performance Correlation Equation, Denki Kagaku, (in Japanese), Vol.60, No.2 (1992), pp.124-130.

(24) Morita, H., Mugikura, Y., Izaki, Y., Watanabe, T. and Abe, T., Analysis of Performance of Molten Carbonate Fuel Cell IV, Performance Formulation Based on Cathode Reaction Mechanism, Denki Kagaku, (in Japanese), Vol.63, No.11 (1995), pp.1053-1060.

(25) Morita, H., Mugikura, Y., Izaki, Y., Watanabe, T. and Abe, T., Analysis of Performance of Molten Carbonate Fuel Cell V, Formulation of Anode Reaction Resistance, Denki Kagaku, (in Japanese), Vol.65, No.9 (1997), pp.740-746.

(26) Koh, J.-H., Kang, B.S. and Lim, H.C., Analysis of Temperature and Pressure Fields in Molten Carbonate Fuel Cell Stacks, AIChE Journal, Vol.47, No.9 (2001), pp.1941-1956.

(27) Yuh, C.Y. and Selman, J.R., The Polarization of Molten
Carbonate Fuel Cell Electrodes, I. Analysis of SteadyState Polarization Data, Journal of Electrochemical Society, Vol.138, No.12 (1991), pp.3642-3648.

(28) Shinoki, T., Matsunaga, M. and Sasaki, A., Development of an Internal Reforming Molten Carbonate Fuel Cell Stack, IEEE Trans. Energy Conversion, Vol.10, No.4 (1995), pp.722-729.

(29) Bosio, B., Costamagna, P., Parodi, F. and Passalacqua, B., Industrial Experience on the Development of the Molten Carbonate Fuel Cell Technology, Journal of Power Sources, Vol.74 (1998), pp.175-187.

(30) Bosio, B., Costamagna, P. and Parodi, F., Modeling and Experimentation of Molten Carbonate Fuel Cell Reactors in a Scale-up Process, Chemical Engineering Science, Vol.54 (1999), pp.2907-2916.

(31) Yoshida, K. (Editor), Exergy Kogaku, (in Japanese), (1999), p.27, Kyoritsu Shuppan.

(32) Nenryou Denchi Hatsuden System Hensyu Iinkai (Editorial Board), Nenryou Denchi Hatsuden System, (in Japanese), (1993), p.106, Ohm-sha.

(33) Uechi, H., Kimijima, S. and Kasagi, N., Cycle Analysis of Gas Turbine-Fuel Cell Cycle Hybrid Micro Generation System, Trans. ASME, Journal of Engineering of Gas Turbine and Power, Vol.126, No.4 (2004), pp.755762.

(34) Dokiya, M., Kobayashi, K., Yasumoto, K., Takahashi, I. and Cai, Z., Feasibility of Reduced Temperature SOFC by Co-Fire Process (Part 2)-The Case of $\mathrm{CeO}_{2}$ and $\mathrm{ZrO}_{2}$ Electrolyte, The 9th Symposium on Solid Oxide Fuel Cell in Japan Extended Abstracts, (in Japanese), (2000), pp.13-20.

(35) Horie, T. and Eda, T., $300 \mathrm{KW}$ Ceramic Gas Turbine: Development of the CGT 302 Heat Exchanger, Journal of Gas Turbine Society of Japan, (in Japanese), Vol.27, No.5 (1999), pp.334-338.

(36) Eguchi, K., High Temperature Catalytic Combustion and Active Catalysts, Petrotech, (in Japanese), Vol.22, No.8 (1999), pp.651-655.

(37) Fukunaga, S., Uechi, H. and Kasagi, N., Development of GUI Software for Cycle Analysis and Conceptual Design of Micro Gas Turbine, Proceedings of the 28th Annual Conference of Gas Turbine Society of Japan, (in Japanese), (2000), pp.141-146. 